\title{
A DESCRIPTIVE STUDY TO ASSESS THE KNOWLEDGE REGARDING ILL EFFECTS OF CARBONATED DRINKS AMONG ADOLESCENTS IN A SELECTED SCHOOL OF, ALAPPPUZHA DISTRICT.
}

\section{Josini. T. Chacko}

\author{
Lecturer , TMM College Of Nursing, Thiruvalla, Kerala University Of Health \\ Sciences.
}

ABSTRACT A non experimental descriptive study was conducted to assess the knowledge regarding ill effects of carbonated drinks among adolescents. The study was conducted in Govt. High school, Nooranadu in Alappuzha district. The objectives of the study were to assess the level of knowledge regarding ill effects of carbonated drinks among adolescents and to find out the association between the levels of knowledge regarding ill effects of carbonated drinks among adolescents with selected socio-demographic variables. Quota sampling technique was adopted to select desired samples. The samples obtained were 60 adolescents in between the age group of $13-18$ yrs studying in 8 th 9 th and 10 standards. The data were collected by means of structured knowledge questionnaire. The result showed that out of 60 samples majority $(85 \%)$ of them having average knowledge , minor proportion (10\%)of them having good knowledge and tiny proportion (5\%) of them having poor knowledge regarding ill effects of carbonated drink. The association between level of knowledge and selected demographic variables showed that only educational status of father had association with level of knowledge( $p$ $<0.05)$

\section{KEYWORDS : Knowledge, Ill Effects, Carbonated Drinks, Adolescents}

INTRODUCTION

Adolescence is a fascinating period of life and it is the most important age after childhood in all societies. Peer influences and education are of highest importance and these experiences ultimate instigate pattern of their life style, especially health habits. Good nutrition is very essential during these age groups for the growth and development.

The consumption of carbonated drinks in youngsters is increasing in alarming proportions. They are often not aware of its health hazards. Scientific studies have shown that one or two soft drinks a day can increase one's risk for numerous health problems. Recent studies have suggested that children who drink a lot of carbonated drinks have the high risk of obesity, bone deformities, cavities, nutritional deficiencies, heart disease, caffeine addiction and many neurological disorders.

India is the third leading country in consuming carbonated drinks. Among the developing countries India is the third leading country with peoples consuming carbonated drinks. Research studies reveals that consumption of carbonated drinks is about $6 \%$ in 2015 and it will be increased up to $10 \%$ in 2020. According to a self-report survey, carbonated drinks are mostly consumed by $30 \%$ to $50 \%$ of adolescents and young adults. It contains high and unregulated amounts of caffeine and these drinks can cause serious adverse effects, especially in children and adolescents.

\section{STATEMENT OF THE PROBLEM}

A descriptive study to assess the knowledge regarding ill effects of carbonated drinks among adolescents in a selected school of Nooranadu Grama Panchayath, Alapppuzha District.

\section{OBJECTIVES OF THE STUDY}

\section{The objectives of the study are}

- To assess the level of knowledge regarding ill effects of carbonated drinks among adolescents.

- To find out the association between the levels of knowledge regarding ill effects of carbonated drinks among adolescents with selected socio-demographic variables.

\section{HYPOTHESIS}

- Ho: There will be no significant association between the mean knowledge score regarding ill effects of carbonated drinks among adolescents and selected sociodemographic variables.
- Hl: There will be a significant association between the mean knowledge score regarding ill effects of carbonated drinks among adolescents and selected socio demographic variables.

\section{RESEARCH METHODOLOGY}

A quantitative research approach in which non experimental descriptive research design was adopted to assess the knowledge regarding ill effects of carbonated drinks among adolescents. The population comprised of adolescents who were in the age group of $13-18$ years studying in $8^{\text {th }}, 9^{\text {th }}$ and $10^{\text {th }}$ standard of Govt. High school, in Alappuzha district. Sampling technique used for the study is quota sampling technique. 60 adolescents in between the age group of 13-18 yrs studying in $8^{\text {th }} 9^{\text {th }}$ and $10^{\text {th }}$ standard who met the inclusion and exclusion criteria were selected as sample

\section{SAMPLING CRITERIA}

Inclusion criteria

Adolescents those who are

- between the age group of 13-18 years

- both boys and girls

- studying in Govt. High School, Edappon

- able to read and write English

- willing to participate in the study

\section{Exclusion criteria}

Adolescents those who are

- absent at the time of data collection.

- not willing to participate in the study

\section{DEVELOPMENT AND DESCRIPTION OF TOOL}

Tool consists of two section

Section A: Socio Demographic Performa to collect demographic data.

Technique: Self administered questionnaire

Section B: Structured knowledge questionnaire

Technique : Self administered questionnaire

\section{SECTION A: Socio Demographic Proforma}

This was designed to elicit the demographic information from the samples, consisted of 12 items. This include age, gender, class of the study, educational status of the father and mother, occupation of mother and father, frequency of consuming carbonated drinks and previous source of knowledge about ill effects of carbonated drinks

SECTION B: Structured Knowledge Questionnaire

The section consist of closed ended questionnaire of 30 items 
to assess the knowledge of adolescents regarding ill effects of carbonated drinks. Each question was given four options carrying one correct answer, The respondents were instructed to select the best possible option and tick () for the most appropriate answer. Each right answer carries the score of one and wrong answer carries a score of zero

The level of knowledge was categorized as Interpretation of knowledge score.

\begin{tabular}{|l|l|l|}
\hline Poor & $0-7$ & $0-25 \%$ \\
\hline Average & $8-15$ & $26-50 \%$ \\
\hline Good & $16-23$ & $51-75 \%$ \\
\hline Excellent & $24-30$ & $76-100 \%$ \\
\hline
\end{tabular}

\section{RELIABILITY OF TOOL}

The reliability of the tool was calculated by using split half method. The reliability of tool was found to be $(r=0.75)$. This indicates that the tool was reliable

\section{DATA COLLECTION PROCESS}

PhaseI: For conducting main study prior permission was obtained from the Principal of Govt.HSS Padanilam.

Phase II: Data collection was done on 15-04-2017. The researcher selected 60 adolescents between 13-18 years of age studying in $8^{\text {th }}, 9^{\text {th }}$, and $10^{\text {th }}$ standards of Govt.HSS Padanilam those who met inclusion and exclusion criteria.. The investigators familiarised themselves with samples and explained the purpose of the study to them; confidentiality was assured to all samples.

Phase III: An informed consent was taken from the samples. A structured knowledge questionnaire was administered to the subjects and collected soon after answering.

\section{DATA ANALYSIS}

Data was analyzed using descriptive and inferential statistics.

- Frequency and percentage distribution was used to describe socio demographic variables.

- Chi-square test was used to find out the association between demographic variables and knowledge of adolescents regarding ill effects of carbonated drinks

\section{RESULTS}

Percentage distribution of sample according to the age group reveals that out of 60 samples more than half $(58.33 \%)$ of the samples were in the age group of 13-14years, more than onethird $(38.33 \%)$ of them were in the age group of 15-16years and a tiny proportion $(3.34 \%$ ) of them were in the age group of 17-18years.According to gender reveals more than two-third $(70 \%)$ of the samples were males and less than one-third $(30 \%)$ of them were females.. Their father's education status shows less than half $(40 \%)$ of the adolescent's fathers were having primary education, more than one-fourth $(26 \%)$ of them were having secondary education, less than one-third $(31.66 \%)$ of them were having higher secondary education and only very less percentage (1.66\%) of them having graduation.

Distribution of adolescents according to their mother's educational status depicts that less than one-fourth(18.33\%) of adolescent's mothers having primary education, less than one-third (30\%) secondary education, less than half $(46 \%)$ having higher secondary education and only minor proportion(5\%) of them having graduation and above. occupation of father shows samples more than half $(51.66 \%)$ of adolescents fathers were daily wager, less than one-fourth (13.33\%) of them were government employers , more than onethird $(35 \%)$ of them were private employers and no samples of fathers were unemployed.

vast majority $(90 \%)$ of them having the habit of consuming carbonated drinks and minor proportion (10\%) of them not having the habit of consuming carbonated drinks. out of 60 samples more than half $(55 \%)$ of them have previous knowledge gained regarding ill effects of carbonated drinks and less than half $(45 \%)$ of them having previous knowledge gained regarding ill effects of carbonated drinks.

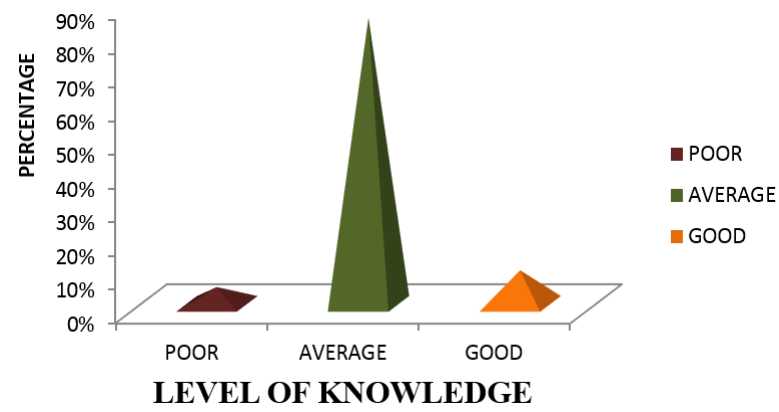

Figl: -Stacked pyramid showing percentage distribution of adolescents according to their level of knowledge.

Inference: The data depicted in Fig 4.14 shows that out of 60 samples majority $(85 \%)$ of them having average knowledge minor proportion (10\%) of them having good knowledge and tiny proportion $(5 \%)$ of them having poor knowledge regarding ill effects of carbonated drink.

Table 2:- Distribution of samples according to the association between the levels of Knowledge of adolescents regarding ill effects and selected demographic variables.

\begin{tabular}{|l|l|l|l|l|l|}
\hline $\begin{array}{l}\text { SI } \\
\text { No. }\end{array}$ & $\begin{array}{l}\text { Demographic } \\
\text { variables }\end{array}$ & df & $\begin{array}{l}\text { Level of } \\
\text { significance }\end{array}$ & Inference \\
\hline 1 & Age & 2.80 & 6 & 12.59 & NS \\
\hline 2 & Gender & 3.12 & 3 & 7.82 & NS \\
\hline 4 & $\begin{array}{l}\text { Educational status of } \\
\text { father }\end{array}$ & 40.38 & 9 & 16.92 & N $^{*}$ \\
\hline 5 & $\begin{array}{l}\text { Educational status of } \\
\text { mother }\end{array}$ & 11.51 & 9 & 16.92 & NS \\
\hline 6 & Occupation of father & 2.73 & 9 & 16.92 & NS \\
\hline 7 & Occupation of mother & 11.69 & 9 & 16.92 & NS \\
\hline 8 & $\begin{array}{l}\text { Habit of drink } \\
\text { carbonated drinks }\end{array}$ & 3.96 & 3 & 7.82 & NS \\
\hline 9 & $\begin{array}{l}\text { Frequency of } \\
\text { consuming carbonated } \\
\text { drinks }\end{array}$ & 13.92 & 9 & 16.92 & NS \\
\hline
\end{tabular}

$\mathrm{S}^{*}$ - significant at 0.05 levels, NS - Not significant

\section{CONCLUSION}

The present study aimed at assessing the knowledge regarding ill effects of carbonated drinks among adolescents in a selected school at Nooranadu Grama Panchayath .The study conclude that majority (85\%) of the samples have average knowledge regarding ill effects of carbonated drinks minor proportion (10\%) had good knowledge and tiny proportion (5\%) of the samples have poor knowledge. Eventhough, adolescents have knowledge on ill effects of carbonated drinks their majority (90\%) of them having the habits of consuming carbonated drinks. So more education is needed in this area to overcome with these problems

\section{REFERENCES}

1. Suwarna Madhukumar, Sudeepa D, Vaishali Gaikwad.Study abou awareness and practices about carbonated drinks among school students. Indian journal of public health research and development. OctoberDecember; 13(4):218-220.

2. Mc Gartland c, Robson P J, Murlay L,Cran G, Savage M J, Watkins D, Rooney $\mathrm{M}$, Boreham $\mathrm{C}$ et al Carbonated soft drink consumption and tone mineral density in Adolescence, J Bone Miner Res. Sep 2003(18): 1563-9.

3. Harnark L, Stang J, Story M Soft drink consumption among as children and Adolescents , J AM Diet Assoc. April, 1999 (4):436-41.

4. Simon C T, Dessirer J M, Csrstens M I, O Mahony M, Carstens E, Neurobiological and psychophysical mechanisms underlying the oral sensation produced by Carbonated water, J Neuroscience ,Sep 1999 (18):13444 